\title{
Political Cycle, Real Exchange Rate and Aggregate Supply in Mexico
}

\author{
Cesáreo Gámez*
}

\begin{abstract}
This paper analyzes the relationship between the political cycle, the real exchange rate and the aggregate supply in Mexico. The period under analysis goes from 1981 to 2007, in which there were five presidential elections: 1982, 1988, 1994, 2000 and 2006. Significant evidence is found of a real appreciation of the peso, an increase in imports and an increase in the aggregate supply in the late months of each Presidential term, followed by a depreciation of the peso, a contraction of imports and a contraction in the aggregate supply in the first months of the new administration. Some conclusions and implications are discussed, as well as some lines for future research.
\end{abstract}

Field of Research: Political Economy

JEL Classification: F31, O24, O54

\section{Introduction}

The purpose of this paper is twofold: on the one hand, to show that there is a relationship between the political cycle and the real exchange rate in Mexico; and, on the other hand, this pattern influence the aggregate supply of the Mexican economy by increasing the import component of the supply in the months previous to elections and changes in the presidential administrations.

In addition to contribute to the better understanding of the Mexican economy, the identification of this pattern is especially relevant for firms operating in Mexico, in particular for those in the export sector, or in industries facing competition from imports.

In previous work (Gámez, 2010) it has been shown that the Mexican economy follows the political business cycle, but in a "partial" way; that is, there is a contraction in the economic activity after elections and changes of federal administrations (the so-called "curse of the first year"), but there is not an expansion before.

In this paper it is shown that there is an expansion before elections and changes of government, but this expansion is not reflected in an increase of the GDP, but in an increase in the aggregate supply, due to an increase in imports. This increase in imports, in turn, is caused by the appreciation of the real exchange rate that takes place in the final months of each presidential administration.

\footnotetext{
*Dr. Cesáreo Gámez. Facultad de Economía, Universidad Autónoma de Nuevo León, México cesareo.gamezgr@uanl.edu.mx
} 


\section{Gámez}

The relevance of the evidence found in this paper goes beyond the Mexican case. As will be shown in the empirical evidence review, in several countries, mainly in Latin America, it has been found a relationship between the political cycle and the behavior of the real exchange rate. The analysis presented here of the relationship between the exchange rate and the aggregate supply can be extended to these countries, or others in similar circumstances.

The period under analysis goes from 1981 to 2007, in which there were five presidential elections: 1982, 1988, 1994, 2000 and 2006. For each election, the behavior of the real exchange rate and aggregate supply is analyzed in a window of 37 months, or 13 quarters around the election dates, which in Mexico take place in July of the electoral years.

The paper is presented in four parts: in the first one an overview of the theoretical framework and empirical evidence is presented, the second part shows the analysis of the real exchange rate, the third part presents the analysis of the aggregate supply and, finally, some conclusions are discussed, as well as some lines for future research.

\section{Literature Review}

Generally speaking, the theoretical framework that supports this investigation is the socalled political business cycle theory, which studies the influence that political events have over some economic variables.

This theory started with the seminal paper by Nordhaus (1975), in which the main assumptions over the behavior of the involved agents are set, assumptions that, with some variations, remain until the present. The logic behind the theory is quite simple: starts with the fact that the state of the economy before an election influences the mood and preferences of the voters. If the economy is doing well, the voters will award the political party in power in the elections by voting for them, if the economy is doing poorly, the voters will "punish" the party in power; in other words, the state of the economy influences the probability of victory of the party in power.

If that is so, and the politicians in power know it, they have a powerful incentive to improve, even in a transitory and artificial way, the state of the economy in the period before elections, in order to increase their probabilities of an electoral victory. These expansions in pre-electoral months, followed by the slowing down in the post-electoral period, are the political business cycle.

The relationship between political cycles and aggregate supply can be traced to Lindbeck (1976), who stated that voters are interested in their real income, and its rate of change. As a result, this author stresses the importance of introducing of the real disposable income and/or its rate of change in the popularity function because of the ease and speed by which governments can "buy" popularity by rising temporarily real income by increasing transfers and public consumption, but also by increasing aggregate supply by cheaper imports. 


\section{Gámez}

Assael and Larraín (1994) develop a formal model for an open economy, where the trade-off between inflation and unemployment is affected by the possibility to manipulate the exchange rate. Such a framework opens a set of scenarios for inflation, output and unemployment around elections. A likely outcome in these circumstances is declining inflation and an appreciation of the real exchange rate before elections.

Frieden and Stein (2000) identify a series of factors that influence the determination of the exchange rate policy in Latin American countries. Among these are the economic structure of the country, the macroeconomic conditions in a given moment, the pressures of various interest groups, the institutional environment and the political schedule.

Regarding this last factor, these authors list some reasons because of which the political cycle, and specially the electoral schedule can have a significant effect in the exchange rate policy and the real exchange rate. First of all, the income effect associated with a depreciation of the local currency in the purchasing power of the population make devaluations or depreciations of the currency a very unpopular measure and, because of that, incumbent politicians try to avoid them (or delay them) in period before elections.

A second reason for the unpopularity of a depreciation of the currency is the fact that, this generally induces a higher rate of inflation, which also has an unpopular effect, which tends to be reflected in the electoral outcome. As a consequence of this, incumbent governments have a strong motivation to launch price stabilization programs in preelectoral periods, frequently based in the use of the exchange rate as an "anchor", which cause an appreciation of the real exchange rate before elections, with the consequent adjustment after.

An additional reason has to do with the "signaling" of competence by incumbent governments. In the perception of common citizens, the competence of governments is associated with their capability to provide public and private goods at the same level of taxes. In an asymmetric information context, governments tend to appreciate the real exchange rate to increase the import component of the aggregate supply (AS=GDP+M) in order to send a signal of competence and thus increase the probabilities of an electoral victory.

All these reasons point to the same direction: it is foreseeable that the real exchange rate tend to appreciate before elections and to depreciate after them. The empirical evidence in many Latin American supports this hypothesis. However, the relationship between the political cycle and the aggregate supply has not been studied so far.

Larraín and Assael $(1995,1997)$ study the main variables of the Chilean economy in nine Presidential terms, finding evidence of the presence of the political cycle in some instrumental variables, such as the money supply, the public deficit and the exchange rate policy. The authors found significant increases in the money supply and the public deficit in the months before the elections, as well as the delay of exchange rate adjustments (devaluations of the currency) until the elections have taken place. 


\section{Gámez}

The Grupo de Análisis para el Desarrollo (GRADE), (1999) studies the exchange rate policy in Peru form 1940 to 1990 . These analysts find that the exchange rate policy is frequently used to increase the short-run conditions of the population, specifically, the real exchange rate tends to appreciate before elections and to depreciate after them. As a result, the political cycle is an important factor in the choosing of the exchange rate policy.

Bonomo and Terra (1999) study the behavior of the exchange rate policy in Brazil between 1964 and 1997, particularly the trade-off between the reduction of inflation caused by the appreciation of the real exchange rate and the effect on the balance of payments provoked by a depreciation. They find significant evidence of the same pattern of a real appreciation of the exchange rate before elections and a depreciation after them.

Ogura (2000) analyzes the Brazilian economy from 1980 to 1999, finding evidence of increases in the growth rate of the GDP, real interest rates and credit supply before the elections and increases in unemployment and inflation, as well as a higher rate of depreciation of the exchange rate in the months following the electoral processes.

Sibley (2001) employs event study methodology to investigate the impact of presidential elections on nominal currency values for a group of 15 Latin American countries between 1980 and 1996, in which there were 41 elections. The results indicate that presidential elections are associated with a statistically significant decline in nominal currency values.

A very interesting finding of the Selby's work is the fact that the main effects on the exchange rate are placed not after the elections, but after the new government takes office. "Our empirical results indicate that the greatest currency depreciation tends to occur at or shortly following the time of inauguration, which is typically two or four months after the election outcome becomes known. This pattern suggests that actions taken by the new President may play an important role in many cases" (p. 19). As a matter of fact, Sibley uses the 1994 election in Mexico as "prime example" of this pattern.

The results found by Sibley suggest that the stage of the political cycle in emerging countries is an important factor influencing exchange rates and should be taken into account when making trade and investment decisions.

Stein and Streb (2004) analyze the relationship between the timing of elections and the behavior of the exchange rate, specially the decisions to devaluate the currency, a measure that has strong political repercussions. The authors study 26 Latin American countries between 1960 and 1994, in which there were 242 elections, 131 of which were Presidential elections. In each case, the authors observed the behavior of the exchange rate in a 19-month period, 9 before and 9 after the elections, considered the month 0 .

The study found evidence that in the months 2, 3 and 4 after the elections the depreciation rate of the currency is higher than in the rest of the period, which support the hypothesis that governments tend to delay devaluations till after the elections in order to increase the probability of victory of the party in power. 


\section{Gámez}

Dreher and Vaubel (2009), investigate a variant of this phenomenon, the effect of the political cycle in the international reserves of the country. These authors examine a data set of 149 countries between 1975 and 2000, finding evidence that in the period prior to elections tend to reduce the amount of international reserves both in relation with the domestic monetary base and the gross domestic product. The authors find this pattern completely consistent with the hypothesis that central banks tend to sell foreign currency in the market in order to appreciate the real exchange rate before elections.

In the case of Mexico, Magaloni (2000) studies the 1976-1997 period. She found increases in public expenditures, private consumption and the rate of growth of the economy before the elections, and a contraction of the economic activity after the elections. She also finds evidence of strategic delays of the adjustments in the exchange rate until the elections have taken place.

Grier and Hernandez Trillo (2004) study the political economy factors that may affect the real exchange rate in Mexico and The United States, finding that, in the case of Mexico elections significantly affect the evolution of the real exchange rate, with an appreciation before elections and a real depreciation of the currency after the electoral process.

Gámez (2010) studies the behavior of the real exchange rate between 1970 and 2010 and identifies a pattern of behavior closely related to the political cycle. The real exchange rate tends to appreciate in the months before elections and to depreciate after them, especially after the new government takes office.

In the case of the relationship between the political cycle and imports, Colunga and Mendez (2010) studied this effect in 15 countries of Latin America and the Caribbean, using monthly data from January, 1990 to December, 2009. These authors found evidence that, in the months $(-3)$ and $(-5)$, before elections, there are significant increases in the imports in the sample studied.

As mentioned before, although there is empirical evidence of the relationship between the political cycle and the exchange rate, the analysis of the relationship between political cycle and aggregate supply has not been done before.

\section{The Real Exchange Rate in Mexico}

In the last decades, the nominal exchange rate regimes in Mexico have gone all over the complete set of possibilities, from a fixed exchange rate from the 50 s until the mid 70 s to the free flotation, which was established in December, 1994 and remaining to the present day. This evolution is shown in the Table 1. 


\section{Gámez}

Table 1: Exchange rate regimes in Mexico since 1954

Date

Regime

\begin{tabular}{ll}
\hline \multicolumn{1}{c}{ Date } & \multicolumn{1}{c}{ Regime } \\
\hline April 19, 1954 - August 31, 1976 & Fixed Exchange rate \\
September 1st, 1976 - August 5, 1982 & Controlled flotation \\
August 6, 1982 - August 31, 1982 & Multiple exchange rate \\
September 1st, 1982 - August 4, 1985 & Exchange rate control \\
August 5, 1985 - November 10, 1991 & Regulated flotation \\
\hline November 11, 1991 - December 21, 1994 & Crawling peg \\
\hline December 22, 1994 - Present day & Free flotation \\
\hline
\end{tabular}

\section{Source: Banco de México (2009)}

However, in spite of the changes on the nominal exchange rate regimes, the real exchange rate has followed an evolution more related with the political cycle, especially with the changes in presidential administrations.

The Banco de Mexico calculates a Pesos's Real Exchange Rate Index (PRERI) against a bundle of 111 foreign currencies, weighted by the relative importance of the commerce of Mexico with each of these currencies.

This index is based $1990=100$, and it is available on monthly basis from January, 1970 to the present. A decrease of the PRERI means a real appreciation of the peso; on the contrary, an increase of the index means a real depreciation of the peso in relation with foreign currencies.

The value of the PRERI from January, 1981 to December, 2007 is shown in Graph 1. This period includes five elections and changes of administration, those which took place in 1982, 1988, 1994, 2000 and 2006. 
Gámez

Graph 1: Pesos's Real Exchange Rate Index (PRERI) 1981-2007

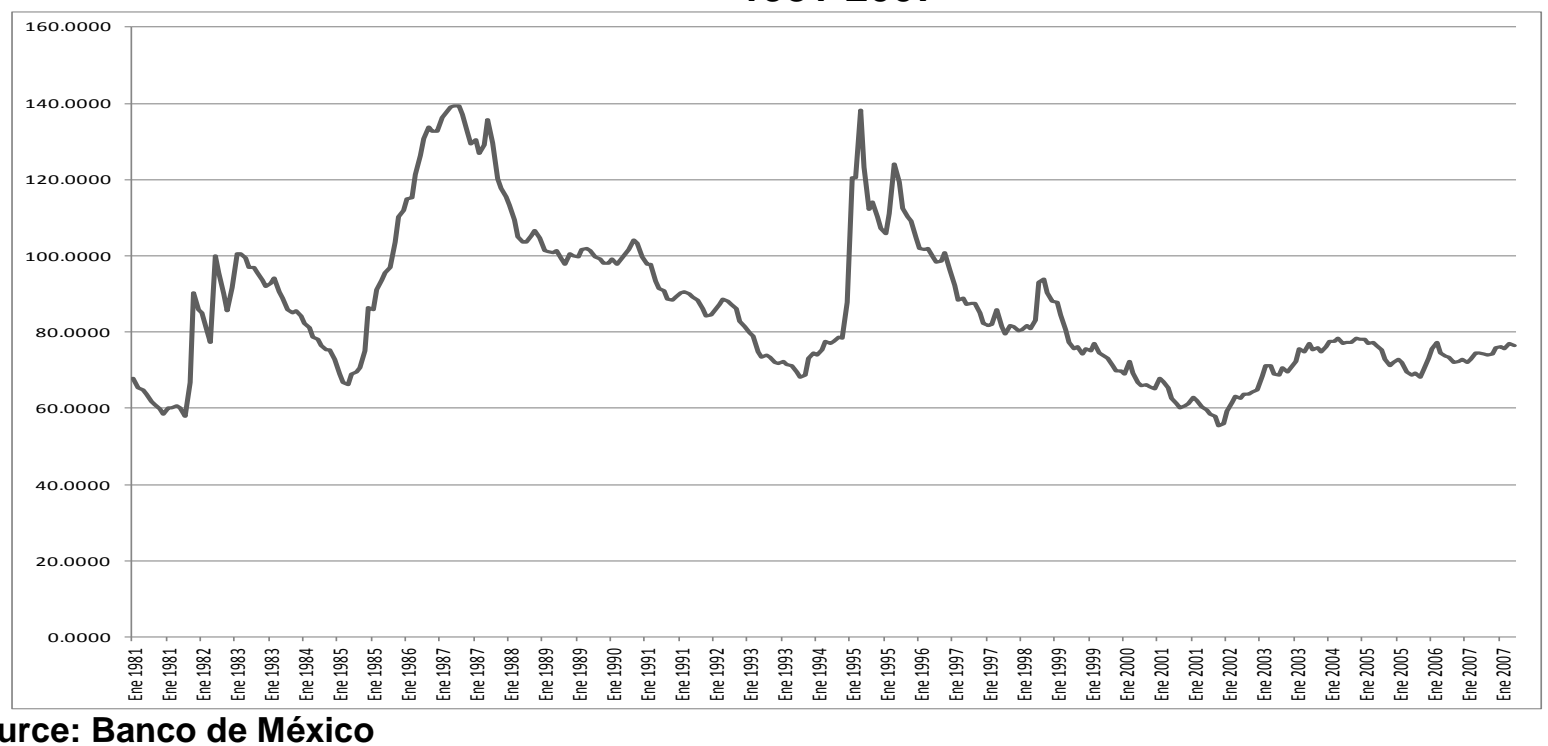

\section{Source: Banco de México}

It can be observed a trend of the PRERI to go downwards, which means a trend to appreciation of the Peso, this trend is interrupted with sporadic and strong adjustments to the rise, which tend to coincide with the electoral years and changes of administration.

In addition to the PRERI, in this work the annual variation of this index (VAR) is analyzed. A positive value of VAR mans a depreciation of the real exchange rate, whereas a negative value represents a real appreciation of the peso in relation with foreign currencies. VAR is shown in Graph 2.

Graph 2: Annual variation of PRERI (VAR) 1981-2007

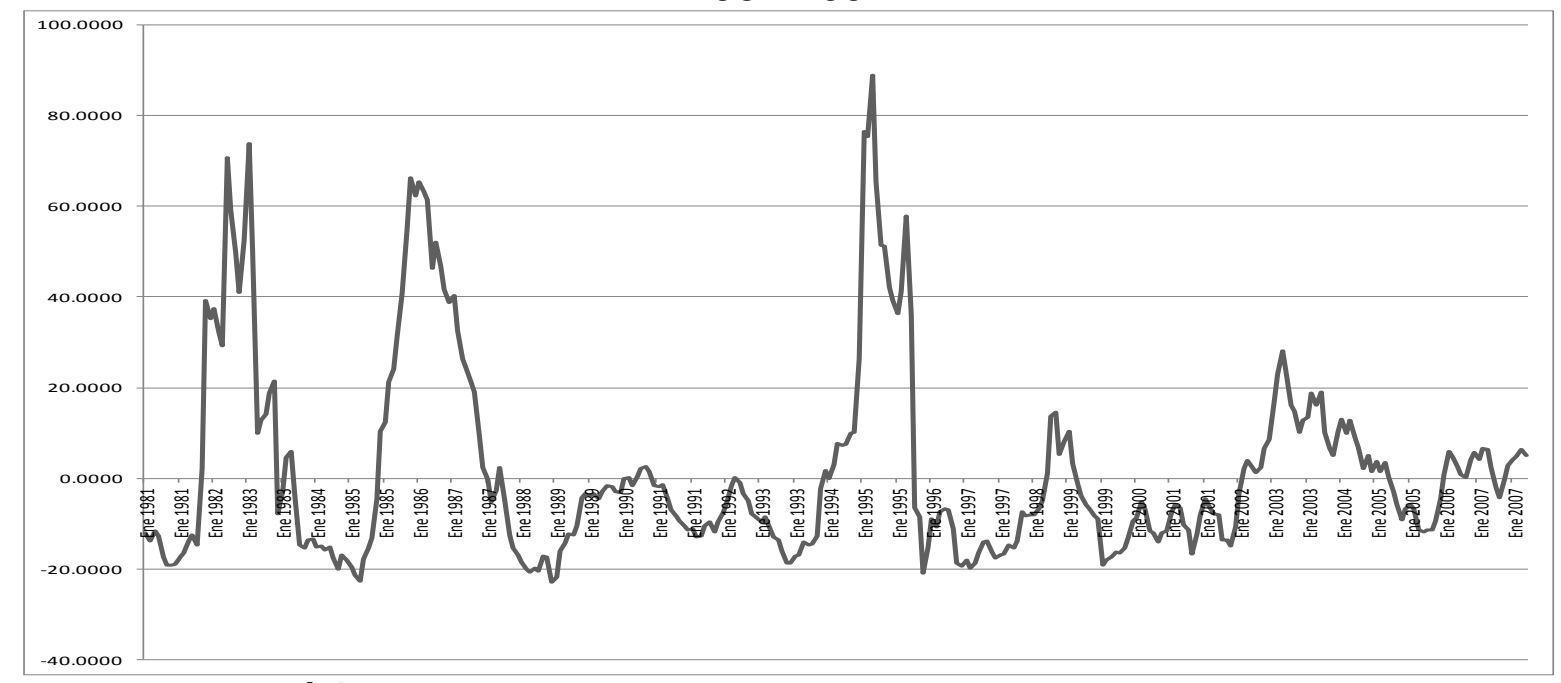

Source: Banco de México 


\section{Gámez}

The majority of the observations of VAR lie in the negative section of the vertical axis, which represents a secular trend towards an appreciation of the peso interrupted by drastic adjustments which tend to coincide with the political cycle.

The behavior of PRERI and VAR is analyzed at two levels: descriptive and econometric. For the statistical analysis the average values of PRERI and VAR are grouped around the relevant political cycle dates; that is, election and change of presidential administration and are shown in Graphs 3 and 4. Month "0" is the election month, usually in July of each election year, and month " 5 " is the month in which the new President takes office, in December of the election year.

\section{Graph 3: Average values of PRERI around elections and changes of administration}

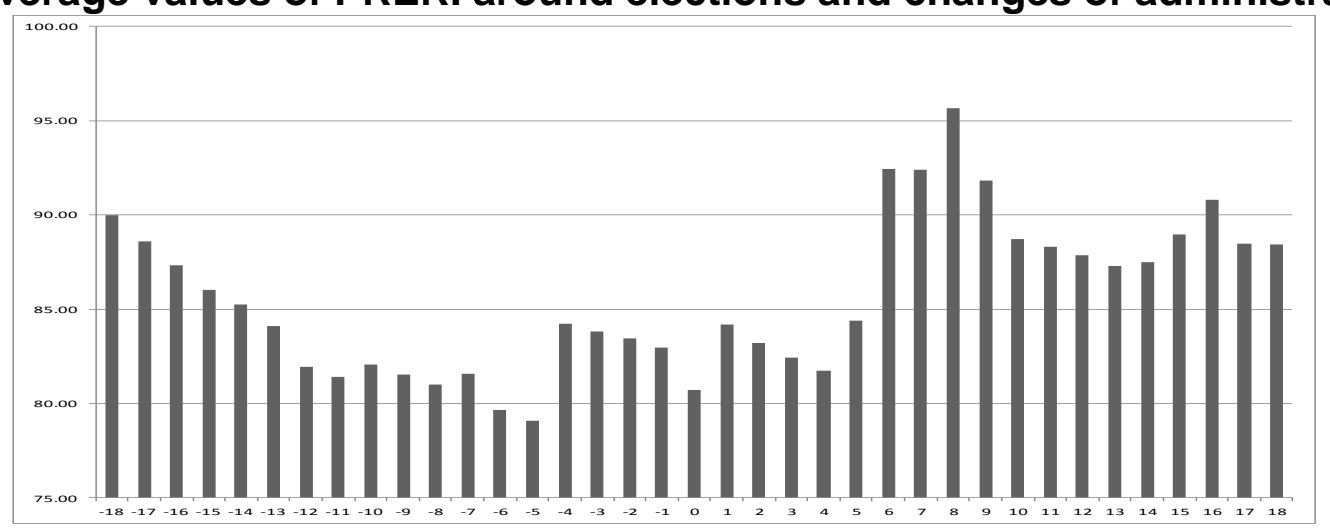

Source: Own elaboration with data from Banco de México

\section{Graph 4: Average values of VAR around elections and changes of administration}

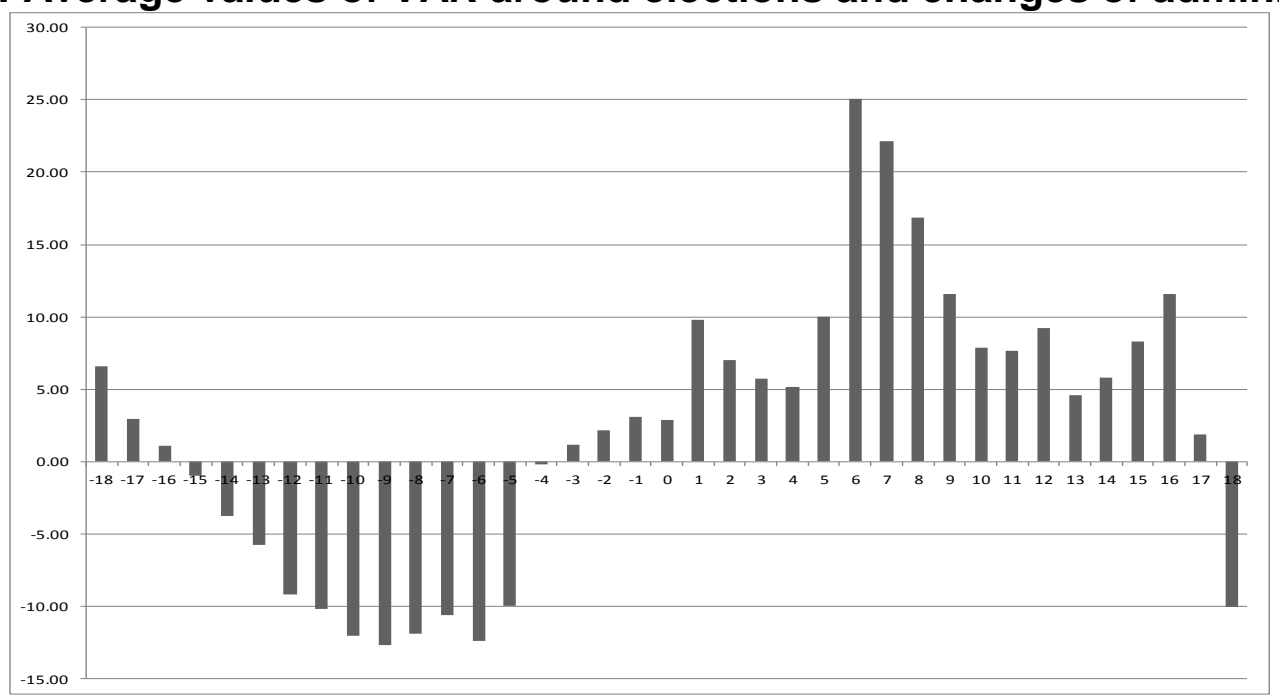

Source: Own elaboration with data from Banco de México

A clear pattern related with the political cycle is observed in both PRERI and VAR. In the case of PRERI there is a downward trend from the month $(-18)$ to the month $(-5)$, a relative stable pattern between the months $(-4)$ to $(4)$, and a increasing trend from the month (5), which is the month of inauguration of the new administration, to the month (8), in July of the following year. 


\section{Gámez}

In the case of VAR, it takes negative values (which mean an appreciation of the peso) in the months $(-14)$ to $(-5)$, which are from April of the year before election to February of the electoral year. On the contrary, from month (1) to month (17) the peso is depreciated, this depreciation being especially strong in the months (6) to (12), which are the first two quarters of the year following elections.

In addition to the statistic analysis, an econometric analysis is made to study the relationship between the real exchange rate and the political cycle. In order to do that, an autoregressive model with dummy variables is used. The dummies are defined for the 18 months previous to elections, the election month, and the 18 months following the elections.

The implicit hypothesis are that the dummies representing the period before elections $(\mathrm{M}(-18)$ to $\mathrm{M}(0))$ have negative signs, reflecting an appreciation of the peso, and the dummies after elections $(M(1)$ to $M(18))$, have positive signs.

Table 2 shows the results of the econometric analysis. Generally speaking, the results are congruent with the patterns observed in the descriptive analysis. Significant negative coefficients can be observed for the months $M(-17), M(-15)$ to $M(-11), M(-9)$ and $M(-6)$. A significant positive coefficient is detected in the month $M(6)$.

Table 2: Econometric results of the analysis of PRERI and VAR

\begin{tabular}{|c|c|c|}
\hline Variable & PRERI & VAR \\
\hline C & 1.679588 & 0.569109 \\
\hline $\operatorname{Lag}(-1)$ & 0.982318 & 0.944418 \\
\hline$M(-18)$ & 0.060534 & 1.065915 \\
\hline$M(-17)$ & -1.447758 & $-3.827^{\star \star \star}$ \\
\hline$M(-16)$ & -1.370007 & -2.225216 \\
\hline$M(-15)$ & $-1.4750^{\star \star}$ & $-2.6020^{\star \star \star}$ \\
\hline$M(-14)$ & -0.93279 & $-3.4111^{\star \star \star}$ \\
\hline$M(-13)$ & $-1.313^{\star \star \star}$ & $-2.7833^{\star \star \star}$ \\
\hline$M(-12)$ & $-2.353^{\star \star \star}$ & $-4.3312^{\star \star \star}$ \\
\hline$M(-11)$ & -0.76056 & -2.059097 \\
\hline$M(-10)$ & 0.424633 & -2.984972 \\
\hline M(-9) & -0.762011 & $-1.90670^{\star}$ \\
\hline M(-8) & -0.767365 & -0.46054 \\
\hline$M(-7)$ & 0.326792 & 0.031055 \\
\hline$M(-6)$ & $-2.1823^{\star \star}$ & $-2.9468^{\star *}$ \\
\hline$M(-5)$ & -0.824293 & 1.166001 \\
\hline$M(-4)$ & 4.869292 & 8.650248 \\
\hline$M(-3)$ & -0.605295 & 0.770371 \\
\hline$M(-2)$ & -0.555334 & 0.501498 \\
\hline$M(-1)$ & -0.696601 & 0.514684 \\
\hline
\end{tabular}




\section{Gámez}

Table 2 (Continued)

\begin{tabular}{|c|c|c|}
\hline Variable & PRERI & VAR \\
\hline MO & $-2.4549^{\star \star}$ & -0.662569 \\
\hline M1 & 3.223377 & 6.561023 \\
\hline M2 & -1.182747 & $-2.85864^{\star}$ \\
\hline M3 & -0.967427 & -1.443811 \\
\hline M4 & -0.94199 & -0.782062 \\
\hline M5 & 2.426174 & 4.535649 \\
\hline M6 & 7.87496 & 15.03549 \\
\hline M7 & -0.09122 & -2.122675 \\
\hline M8 & 3.208521 & -4.552851 \\
\hline M9 & -3.823298 & -4.933559 \\
\hline M10 & $-3.15629^{*}$ & $-3.62390^{*}$ \\
\hline M11 & -0.521313 & -0.339915 \\
\hline M12 & -0.575972 & 1.431333 \\
\hline M13 & -0.675569 & -4.756063 \\
\hline M14 & 0.065775 & 0.964092 \\
\hline M15 & 1.32108 & 2.186128 \\
\hline M16 & 1.723099 & 3.218992 \\
\hline M17 & $-1.8904^{\star \star}$ & $-7.33336^{\star}$ \\
\hline M18 & $-3.282^{\star \star \star}$ & $-14.8001^{*}$ \\
\hline $\mathbf{R}^{2}$ & 0.965714 & 0.906661 \\
\hline Adj $R^{2}$ & 0.961143 & 0.894215 \\
\hline F-stat & 211.2494 & 72.8519 \\
\hline Prob(F) & 0 & 0 \\
\hline
\end{tabular}

*Significant at $90 \%$ * Significant at $90 \%$ ** Significant at 95\%

Source: Elaborated with information from Banco de México

Generally speaking, the signs of the dummy variables are the expected in the months prior to the elections, with negative signs and statistical significance in the months $M(-15)$ to $M(-12)$. However, in the months after elections the results are less clear. In the case of $\mathrm{VAR}$, the coefficient of the dummy $\mathrm{M}(6)$ is marginally significant (prob $=0.12$ ).

These results are consistent with those observed in other countries of Latin America and we can conclude that in the period under analysis the real exchange rate in Mexico has followed a pattern closely related with the political cycle, with appreciations in the last months of each Presidential administration, followed by a depreciation, in some cases very drastic, in the first months of the new administration.

It is worth noting that this pattern of behavior of the real exchange rate in Mexico remained even after the independence of the Banco de México (December, 1993) and the introduction of the free flotation regime, in December, 1994 (Gámez, 2010b, 2012). 


\section{Gámez}

\section{The Aggregate Supply}

Once stated the relationship between the political cycle and the real exchange rate in Mexico, one question that comes to mind is: What is the effect of this pattern in the behavior of imports and the aggregate supply of the economy?

The implicit hypothesis is: the appreciation of the peso will, "ceteris paribus" reduce the real price of imported goods and, as a result, increase the proportion of imports in the aggregate supply, and the aggregate supply itself, in the months before elections and changes of administration. In this section this hypothesis is going to be tested.

The information used in this analysis is taken from the INEGI, the official agency of statistics in Mexico. This information is available on quarterly basis since the first quarter of 1980 to the present. The variables analyzed here are the annual rates of growth of the aggregate supply (AG), imports (M) and the gross domestic product (GDP).

The period analyzed goes from the first quarter of 1981 to the fourth quarter of 2007 . As in the case of the real exchange rate, the analysis is done at descriptive and econometric levels. Graph 5 shows the aggregate supply (AS) and its components: Gross domestic product (GDP) and imports (M) for the entire period.

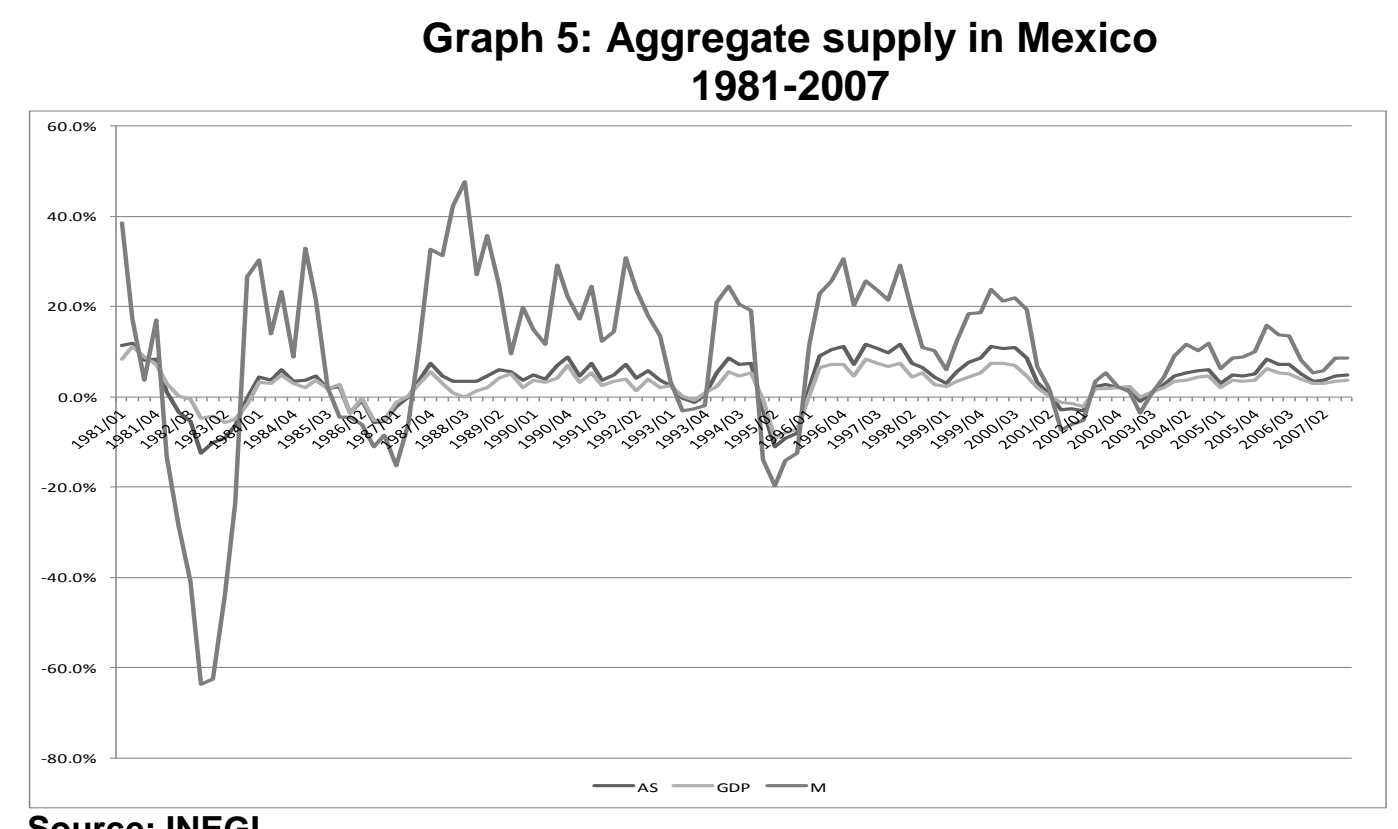

Source: INEGI

For the statistical analysis the values of the variables are grouped around the election and inauguration dates. Elections take place in $Q(0)$, whereas $Q(2)$ is the first quarter of the new administration. The average values of these variables in the period are shown in Graph 6. 


\section{Gámez}

Graph 6: Average values of AS, M and GDP around elections and changes of administration

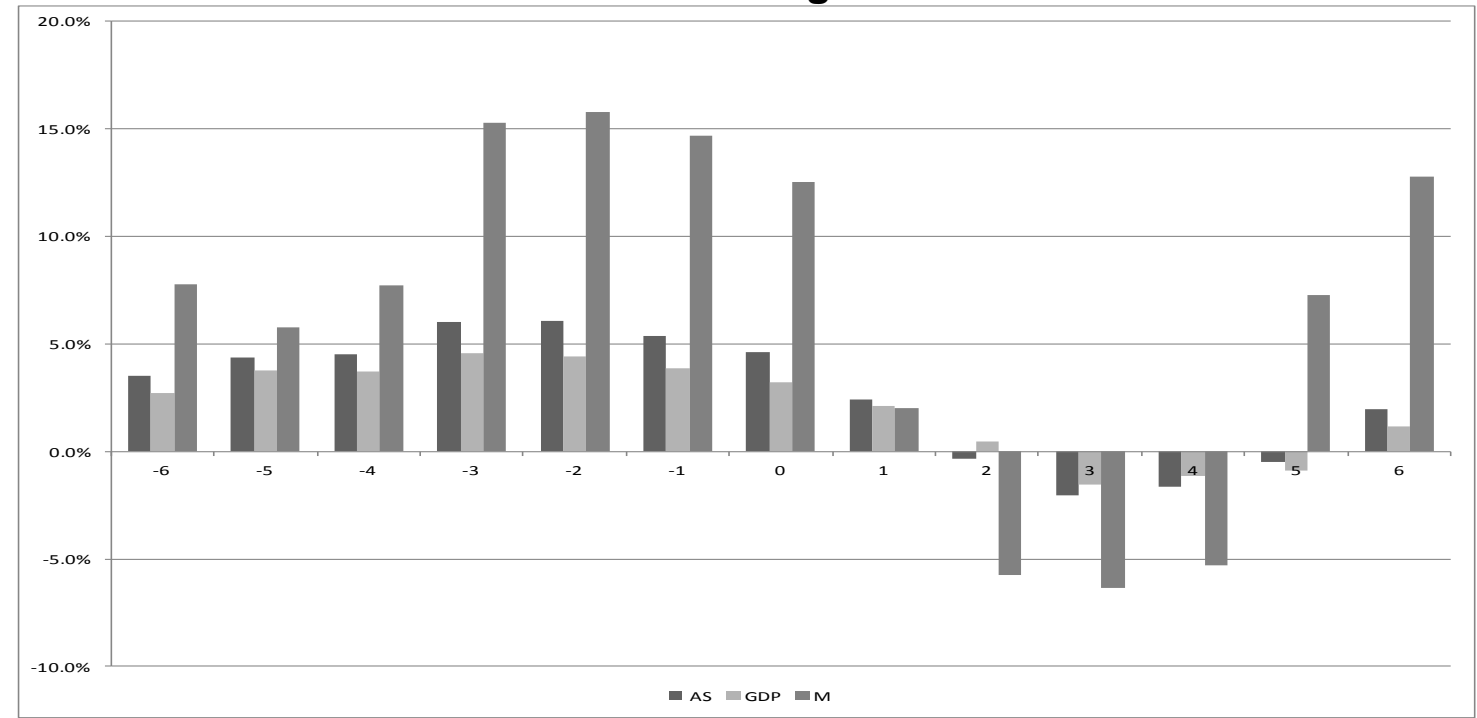

Source: Own elaboration with data from INEGI

The behavior of AS, M and GDP follow a pattern around election and inauguration dates, with increases above the average in the quarters before inauguration, particularly in $Q(-3)$ to $Q(1)$. This pattern is reversed from $Q(2)$, which is the inauguration quarter, $Q 83)$ and $\mathrm{Q}(4)$, with negative values of the three variables.

For the econometric analysis, an autoregressive model with dummy variables is used, as in the case of the real exchange rate. In this model, 13 dummy variables are defined, six for the quarters before elections $(Q(-6)$ to $Q(-1)$, the election quarter $Q(0)$, and six for the quarters following elections $(Q(1)$ to $Q(6)$. The hypothesis are that the dummies representing the quarters before elections $(Q(-6)$ to $Q(0))$ will have positive signs, whereas the dummies representing the quarters after elections $(Q(1)$ to $Q(6))$ will have a negative sign. The results are shown in Table 3. 


\section{Gámez}

Table 3: Econometric results of the analysis of AS, M and GDP

\begin{tabular}{cccc}
\hline Variable & $\begin{array}{c}\text { Aggregate Supply } \\
\text { (AS) }\end{array}$ & $\begin{array}{c}\text { Imports } \\
\text { (M) }\end{array}$ & $\begin{array}{c}\text { Gross Domestic Product } \\
\text { (GDP) }\end{array}$ \\
\hline C & 0.009385 & 0.021616 & 0.008059 \\
Lagged(-1) & 0.801661 & 0.803235 & 0.746118 \\
Q(-6) & -0.011470 & $-0.075^{* * *}$ & -0.002488 \\
Q(-5) & 0.006074 & -0.026165 & 0.009302 \\
Q(-3) & 0.001121 & 0.008965 & 0.001039 \\
Q(-2) & $\mathbf{0 . 0 1 4 2 * *}$ & 0.069328 & 0.009736 \\
Q(-1) & 0.003443 & 0.013281 & 0.001869 \\
Q0 & -0.004661 & -0.001663 & -0.002154 \\
Q1 & -0.006084 & -0.014183 & -0.004688 \\
Q2 & -0.022509 & $-0.10208^{\star}$ & -0.011076 \\
Q3 & $-0.03211^{*}$ & -0.095006 & $-0.0190^{\star *}$ \\
Q4 & -0.026999 & -0.039185 & -0.027032 \\
Q6 & -0.009395 & -0.023581 & -0.007946 \\
R-squared & -0.000984 & 0.093440 & -0.008620 \\
Adjusted R-squared & 0.024747 & 0.050776 & 0.018833 \\
F-statistic & 0.729345 & 0.713838 & 0.663547 \\
Prob(F-statistic) & 0.688159 & 0.670291 & 0.612347 \\
\hline
\end{tabular}

*Significant at $90 \%$ * Significant at $90 \%$ ** Significant at 95\%

Source: Own elaboration with data from INEGI

Generally speaking, the signs of the coefficients are the expected in the quarters around elections and inauguration, especially in $\mathrm{Q}(-3)$, which in the last quarter of the year prior to elections. In this quarter the signs of the three variables are the expected, being significant the coefficients of AS and GDP. In the case of $M$, the coefficient is only marginally significant (Prob $=0.1088$ ).

The signs of the coefficient of the dummies after inauguration are also the expected, being significant the coefficient of $Q(1)$ for imports and Q(2) for the GDP. In the case of the aggregate supply, the sign of $Q(2)$ is only marginally significant (Prob=0.1092).

These results are consistent with those found in the descriptive analysis, supporting the evidence that there is a cyclical pattern associated with the political calendar in the aggregate supply in Mexico in the period under study.

\section{Conclusions and Limitations}

This work presents evidence that there is a pattern associated with the political cycle in Mexico in the real exchange rate of the peso in relation with foreign currencies, and this pattern is reflected in the aggregate supply of the Mexican economy.

Specifically, there is a real appreciation of the peso in the final months of each Presidential administration, followed by a depreciation in the first months of the following term, this pattern is reflected in the aggregate supply, by an increase in both the imports and the GDP.

These patterns are consistent with those already identified in some other Latin American countries. In the case of the real exchange rate, its relationship with the political cycle has been studied in several countries, as mentioned before. The relationship between 


\section{Gámez}

the political calendar and the behavior of imports and aggregate supply has not been so extensively investigated.

The identification of a pattern associated with the political cycle in the real exchange rate has important implications for the firms operating in Mexico, because it provides elements to improve financial planning, hedging, project evaluation and other important areas of corporate finance.

One advantage of the political business cycle over other economic phenomena is the fact that it follows a regular pattern, and, because of that, it is predictable. Knowing in advance the probable behavior of an economic variable allows firms to design strategies to protect from it and, eventually to take advantage of it.

In this case, the evidence presented here is especially relevant to firms in the export sector, or firms in industries facing competence from imported goods. The anticipation of an appreciation of the peso in the final months of each administration with the effects associated in the relative price of imports, and the depreciation following the change of administration, can provide elements to complement and enrich financial planning, debt and hedging strategies in prevention of these factors.

One of the main limitations of this work is that it is confined to a single country; in this case, México. However, It is important to emphasize that the implications of the findings reported here can be extended beyond the Mexican case.

In countries where the relationship between the political cycle and the exchange rate has been already identified (Chile, Brazil, Peru and other Latin American countries), it could be expected that this relationship can have effects on the aggregate supply similar to those identified in Mexico, with the consequences mentioned above.

Regarding the lines for future research, one could be to extend the analysis of the effect of the political cycle on the aggregate supply to other emerging countries, specially to those in which it has already been identified a pattern in the real exchange rate.

Another interesting line of research would be to extend the analysis to the study of the aggregate demand $(\mathrm{C}+\mathrm{G}+\mathrm{I}+\mathrm{M})$ around elections and changes of administration. According with existent evidence (Gámez, 2010, 2012), one of the sectors most affected by the political cycle in Mexico is the building industry, which, in turn, is very important for the formation of fixed capital (I). The hypothesis to test would be that the political cycle affects the rate of formation of fixed capital, and the implicit costs that this could mean for the economy.

Summarizing, the existence of a pattern related with the political cycle in the real exchange rate, aggregate supply and imports, and the knowledge of that pattern, can contribute to improve the understanding of the Mexican economy, and provide elements to the operation, planning and profitability of the firms operating in this country, and should be taken into consideration in evaluation and decision making. 


\section{Gámez}

\section{References}

Assael, P, and Larraín, F 1994. 'El Ciclo Político Económico: Teoría, Evidencia y Extensión para una Economía Abierta', Cuadernos de Economía. Año 31, No 92. pp 87-113.

Banco de México 2009. Regímenes cambiarios en México a partir de 1954.<http://www.banxico.org.mx/sistema-financiero/materialducativo/basico/\%7B51CCA803-9DB0-9162-1CFA-B19CE71599DB\%7D.pdf>

Banco de México 2010. "Indice de Tipo de Cambio Real: Índice Multilateral con 111 Países". Internal document.

Bonomo, M and Terra C 1999. 'The Political Economy of Exchange Rate Policy in Brazil: 1964-1997'. Banco Interamericano de Desarrollo. Documento de Trabajo R 367.

Colunga, F and Méndez, A 2010. 'El Ciclo Político y las Importaciones: Evidencia para América Latina y el Caribe'. Paper presented in the course El Ciclo Político Económico. Universidad Autónoma de Nuevo León. Facultad de Economía. Mexico

Dreher, A and Vaubel, R 2009. 'Foreign Exchange Interventions and the Political Business Cycle: a Panel Data Analysis'. Journal of International Money and Finance. 28 pp 755-774.

Frieden, J and Stein,E 2000. 'The Political Economy of Exchange Rate Policy in Latin America: An Analytical Overview'. Inter-American Development Bank. Working paper $R-420$

Gámez, C 2010. El Ciclo Político y la Economía Mexicana. Universidad Autónoma de Nuevo León. Mexico.

Gámez, C 2010b. ‘El Ciclo Político y el Tipo de Cambio Real en México’. Paper presented in the conference El Ciclo Político Económico en América Latina. Universidad Autónoma de Nuevo León. Facultad de Economía. Mexico. August 20. Gámez, C 2012. Política y Economía: El ciclo sexenal en México. Plaza y Valdés. México.

Grier, K B. and Hernández Trillo, F 2004. 'The Real Exchange Rate and its Real Effects: The cases of Mexico and the USA'. Journal of Applied Economics. Vol VII, No 1. pp 1-25.

Grupo de Análisis para el Desarrollo (GRADE) 1999. 'The Political Economy of

Exchange Rate Policies in Latin America and the Caribbean'. Banco Interamericano de Desarrollo. Documento de trabajo $R-365$.

Larraín, Felipe and Paola Assael 1995. "Cincuenta Años de Ciclo Político-Económico en Chile". Cuadernos de Economía, 96, pp.129-150.

Larraín, F and Assael, P 1997. 'El Ciclo Político Económico en Chile en el Ultimo Medio Siglo'. Estudios Públicos.68, pp.197-214.

Magaloni, B 2000. 'Institutions, Political Opportunism and Macroeconomic Cycles: México 1970-1998'. Working paper. Stanford University

Nordhaus, W D 1975. 'The Political Business Cycle'. The Review of Economic Studies. Vol 42, Num 2. pp 169-190.

Ogura, LM 2000. 'Political Business Cycles in Brazilian Economics (1980-1999)'. Working paper. University of Brazilia. Departament of Economics

Sibley, M 2001. 'The Impact of Presidential Elections on Currency Values in Latin America'. Multinational Business Review, 9 (2). Pp 14-19 


\section{Gámez}

Stein, EH and Streb, JM 2004. 'Elections and the Timing of Devaluations'. Journal of International Economics. 63, pp 119-145. 